\title{
EFEKTIFITAS PERMENDAG NO 24 TAHUN 2020 TENTANG PENETAPAN HARGA PEMBELIAN PEMERINTAH (HPP) UNTUK GABAH ATAU BERAS DALAM MENGHADAPI KRISIS PETANI DI INDONESIA
}

\section{FARIDA SEKTI PAHLEVI}

Fakultas Syariah IAIN Ponorogo

\begin{abstract}
Indonesia is an agrarian country where most of the people make a living as farmers. The need for food is a priority for the survival of the nation. The welfare of farmers is influenced by the condition of farmers in market access and profits from harvests. Agricultural law policies should be able to provide protection against all challenges faced by Indonesian farmers, especially related to the price of grain or rice harvests. Great agricultural potential, there should be a government policy in the welfare of farmers' lives by fixing the government's purchase price for crops, especially grain or rice. After the issuance of Minister of Trade Regulation No. 24 of 2020, it turns out that farmers are still disappointed with the determination of the HPP. The purpose of this journal is to explain the effectiveness of Minister of Trade Number 24 of 2020 in dealing with the farmers' crisis in Indonesia. The method used is literature study sourced from journals, regulations and articles related to the Minister of Trade policy number 24 of 2020. The results of this journal show that the farmers' crisis in Indonesia occurs because of the dissatisfaction of farmers with the benefits obtained so that the community, especially the next generation Young people are reluctant to choose a farmer's livelihood. Minister of Trade Regulation No. 24 of 2020 comes as part of the government's efforts to maintain the stability of grain or rice prices, but it has not been effective in preventing the farmers' crisis in Indonesia.
\end{abstract}

Keywords: Effectiveness, PERMENDAG, Farmers Crisis

ABSTRAK: Indonesia adalah negara agraris yang sebagian besar masyarakatnya bermata pencaharian sebagai petani. Kebutuhan pangan menjadi hal yang diutamakan demi keberlangsungan hidup bangsa. Kesejahteraan petani dipengaruhi oleh kondisi petani dalam akses pasar dan keuntungan dari hasil panen. Kebijakan hukum pertanian hendaknya dapat memberikan perlindungan terhadap semua tantangan yang dihadapi oleh petani Indonesia khususnya terkait dengan harga hasil panen gabah atau beras. Potensi pertanian yang besar, hendaknya perlu adanya kebijakan pemerintah dalam mensejahterakan kehidupan petani dengan penetapan harga pembelian pemerintah hasil panen khususnya gabah atau beras. Setelah terbitnya permendag no 24 tahun 2020, ternyata masih ditemukan kekecewaan petani terhadap penetapan HPP tersebut. Tujuan dari jurnal ini yaitu, memaparkan efektifitas permendag nomor 24 tahun 2020 dalam menghadapi krisis petani di Indonesia. Adapun metode yang digunakan yaitu studi pustaka bersumber dari jurnal, peraturan-peraturan dan artikel yang berkaitan dengan kebijakan permendag nomor 24 tahun 2020. Hasil dari jurnal ini yaitu menunjukkan bahwa krisis petani di Indonesia terjadi karena adanya ketidakpuasan petani terhadap 
keuntungan yang didapatkan sehingga masyarakat khususnya generasi muda enggan memilih bermatapencaharian petani. Permendag no 24 tahun 2020 hadir menjadi salah satu bagian ikhtiar pemerintah dalam menjaga stabilitas harga gabah atau beras, akan tetapi belum efektif dalam mencegah krisis petani di Indonesia.

Kata Kunci: Efektifitas, PERMENDAG, Krisis Petani

\section{PENDAHULUAN}

Ketahanan pangan dan kesejahteraan bagi petani harus dijamin oleh negara Indonesia. Sektor pertanian di Indonesia memiliki beberapa permasalahan, di antaranya sulitnya meregenerasi petani, produktivitas pertanian yang rendah, harga jual komoditas pertanian yang sering dipermainkan oleh tengkulak, pemilikan lahan pertanian yang relatif sempit bagi petani, alih fungsi lahan pertanian menjadi lahan nonpertanian. Sektor pertanian akan semakin melemah apabila permasalahan yang terjadi tidak segera ditindaklanjuti untuk diselesaikan. Jangka panjang krisis petani dikhawatirkan dapat mengakibatkan terjadinya krisis bahan pangan. ${ }^{1}$ Permasalahan pertanian sebagian timbul karena tumpang tindih dan ketidakadilan dari beberapa kebijakan pemerintah yang kurang memihak pada sektor pertanian.

Sektor pertanian merupakan sektor yang memiliki peranan penting dalam perekonomian nasional. Pertanian harus diperhatikan dengan baik demi kelangsungan hidup masyarakat, sumber lapangan kerja dan sumber penyedia kebutuhan pangan dalam negeri. ${ }^{2}$ Pertanian adalah kegiatan pemanfaatan sumber daya hayati yang dilakukan manusia untuk mengahasilkan bahan pangan, bahan baku industri, atau sumber energi, serta untuk mengelola lingkungan hidup. Sektor pertanian adalah sektor yang paling utama dalam perekonomian untuk menopang kehidupan produksi sektorsektor lainnya seperti subsektor perikanan, subsektor perkebunan, subsektor perternakan. ${ }^{3}$

Indonesia sebagai negara agraris memiliki potensi besar dalam bidang pertanian. Bidang pertanian harus diperhatikan dengan tujuan untuk meningkatkan kesejahteraan rakyat, menjaga ketersediaan pangan, dan membangun pertanian sebagai sektor unggulan. Potensi sektor pertanian dapat memberikan kontribusi besar bagi perekonomian masyarakat. Sektor pertanian dapat memberi sumbangan besar bagi pertumbuhan perekonomian negara melalui multiplier effect (efek pengganda) yang besar dalam hubungannya dengan sektor-sektor lain.

Kekecewaan petani terhadap harga hasil panen sering terjadi. Peneliti mendapakan data dari berbagai sumber diantaranya bahwa petani Lamongan kecewa terhadap anjloknya harga gabah saat panen tiba. Harga Pembelian Pemerintah (HPP) gabah kering di tingkat petani saat ini Rp 4.000/kg, padahal, HPP gabah di Lamongan

${ }^{1}$ I Ketut Suratha, “Krisis Petani Berdampak pada Ketahanan Pangan di Indonesia” Jurnal Media Komunikasi Geografi Vol. 16 No.1 ( 2015), 68-82.

2 Julius r latumaresa, Perekonomian Indonesia Dan Dinamika Ekonomi Global (Jakarta: Mitra Wacana Media, 2015).

${ }^{3}$ Iskandar Putong, Teori Ekonomi Mikro (Jakarta: Mitra Wacana Media, 2005). 93 
mencapai Rp 4.200/kg. Yang lebih memperihatinkan adalah harga saat awal panen hanya berkisar antara Rp 3.700 hingga Rp 3.900/kg. ${ }^{4}$

Kemudian ada peristiwa di wilayah Dompu Nusa Tenggara Barat petani juga merasa kecewa dan tidak puas dengan harga jual Gabah dan beras yang tidak seimbang dengan biaya yang dikeluarkan selama menanam padi. Pada bulan Maret 2021 harga gabah petani dengan kering panen berada di kisaran Rp3.700-Rp3.900/kg. Harga ini berada di bawah HPP yang ditetapkan Rp4.200/kg. Tapi HPP tersebut dengan kadar air (KA) maksimal 25 persen dan kadar hampa maksimal 10 persen. Harga Rp3.700 Rp3.900/kg itu sudah sesuai dengan kadar air gabahnya. Kendati demikian, petani merasa masih kecewa dengan realita yang ada. ${ }^{5}$

Peneliti mendapatkan data dari Badan Pusat Statistik (BPS) bahwa ternyata menemukan kasus harga gabah dibawah PPH, yaitu sebagai berikut selama tahun 2021:6

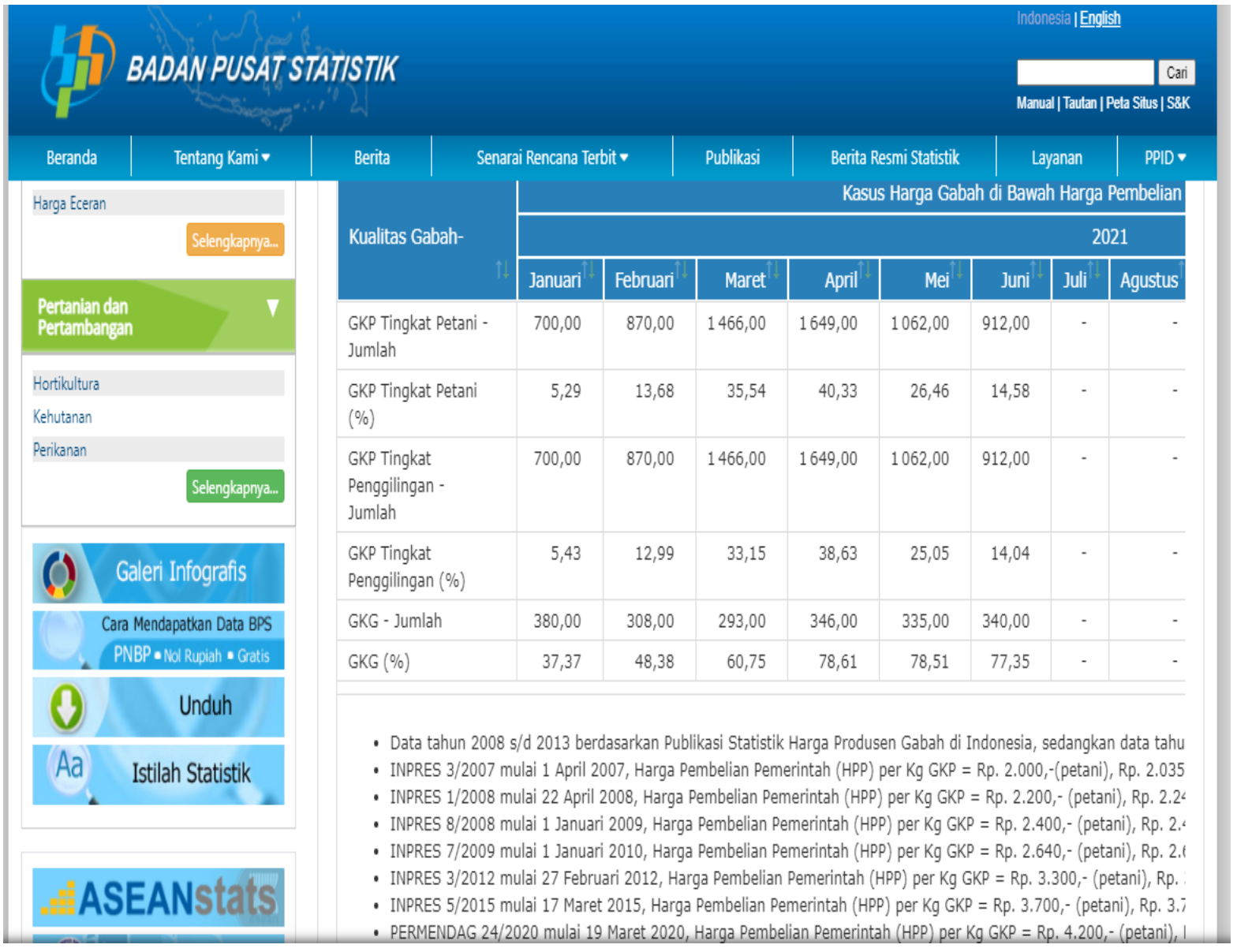

dengan keterangan;7 (a) GKP adalah Gabah Kering Panen, (b) GKS adalah Gabah Kering Simpan dan (c) GKG adalah Gabah Kering Giling

${ }^{4}$ Eko Sudjarwo, "Harga Gabah Murah, Petani Keluhkan Kebijakan Pemerintah Impor Beras," detiknews, diakses 5 Juli 2021, https://news.detik.com/berita-jawa-timur/d-5499504/harga-gabah-murah-petanikeluhkan-kebijakan-pemerintah-impor-beras.

5 SUARANTB.com, "Kecewa Harga Gabah Anjlok, Petani Dompu Potong Padinya | SuaraNTB,” 30 Maret 2021, https://www.suarantb.com/kecewa-harga-gabah-anjlok-petani-dompu-potong-padinya/.

6 "Badan Pusat Statistik," diakses 2 Juli 2021, https://www.bps.go.id/indicator/36/1052/1/kasusharga-gabah-di-bawah-harga-pembelian-pemerintah-hpp-bulanan.html. 
Dengan demikian, bisa dikatakan bahwa dengan adanya peraturan HPP yang dikeluarkan oleh menteri perdagangan ternyata masih banyak ditemukan kasus harga gabah atau beras dibawah HPP. Hal ini membuktikan bahwa penetapan HPP belum mampu memberikan kesejahteraan bagi para petani. Kekecewaan petani terhadap harga pembelian hasil panen gabah atau beras bisa menjadi faktor terjadinya krisis petani di Indonesia. Keengganan masyarakat khususnya generasi muda untuk bermatapencaharian menjadi petani dapat menurunkan jumlah petani di Indonesia, yang akan berimbas kepada ketahanan pangan nasional.

\section{FAKTOR PENYEBAB KRISIS PETANI DI INDONESIA}

Petani di Indonesia mengalami pasang surut baik dari segi jumlah petani, hasil pertanian, ataupun keuntungan dari hasil panen. Lahan pertanian yang dahulunya luas, lambat laun semakin menyempit. Ancaman terjadinya krisis petani banyak disampaikan oleh para peneliti diberbagai jurnal ilmiah. Kehhawatiran pemerintah terkait hal serupa juga sering mewarnai media masa. Strategi bermunculan seiring tumbuhnya peniurunan jumlah petani di Indonesia. Banyak factor yang mengakibatkan terjadinya krisis petani. Jumlah petani di Indonesia menunjukkan semakin berkurang, salah satunya yang disampaikan dalam koran Jakarta yang bersumber dari data BPS, yaitu: ${ }^{8}$

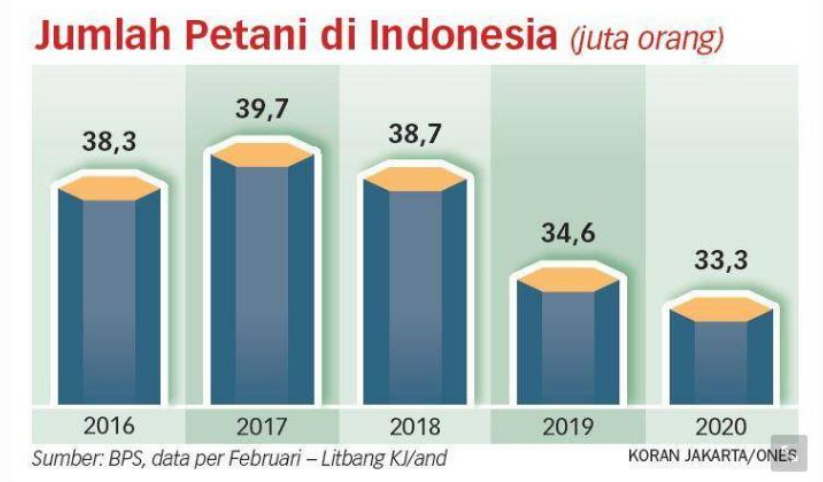

Melihat data tersebut, krisis petani sangat mungkin terjadi di Indonesia. Sebagai langkah antisipasi maka pemerintah harus mengeluarkan strategi guna mencegah krisis petani di Indonesia.

Faktor-faktor penyebab terjadinya krisis petani diantaranya adalah :

1. Krisis peminat dari kalangan generasi muda

Pada tahun 2020 ada data BPS menyampaikan bahwa ada sekitar 33,4 juta petani yang bergerak pada sector pertanian. Jumlah tersebut lebih rendah dibandingakan dengan jumlah petani tahun 2019 berjumlah 34,58 juta. Apabila dibandingkan dengan jumlah petani tahun 2018 juga mengalami penurunan yaitu berjumlah 35, 70 juta jiwa. Semakin banyaknya penurunan jumlah petani

${ }^{7}$ URL PROFIL FB, "Pengertian GKP, GKS dan GKG dalam dunia Pertanian," Sampul Pertanian (blog), diakses 2 Juli 2021, https://www.sampulpertanian.com/2017/10/pengertian-gkp-gks-dan-gkg-dalamdunia.html.

${ }^{8}$ Koran Jakarta, "Pendampingan ke Petani Mesti Terus Diperluas | Koran Jakarta," LINE TODAY, diakses 14 Juni 2021, https://today.line.me/id/v2/article/1eaB6z. 
dari tahun ketahun maka regenerasi petani harus serius diperhatikan untuk menghadirkan petani baru sebagai wujud upaya menghadapi krisis petani di Indonesia. ${ }^{9}$ Hasil Survei Pertanian Antar Sensus tahun 2018 terdapat kelompok petani dengan rentang usia > 54 tahun yang berjumlah 10.379.211 jiwa, kemudian petani usia muda rentang usia 25-34 tahun hanya berjumlah 2.722.446 jiwa. ${ }^{10}$ Jumlah petani Indonesia menunjukkan penurunan karena minat remaja yang rendah terhadap sektor pertanian. ${ }^{11}$

2. Alih fungsi/konversi lahan pertanian menjadi lahan non pertanian

Alih fungsi lahan pertanian menjadi lahan non pertanian telah menyebabkan luas lahan pertanian menurun di Indonesia, terutama luas lahan baku sawah yang menurut data dari BPS tinggal seluas 7,1 juta hektar pada tahun 2018.12 Angka ini telah menunjukkan penurunan jika dibandingkan luas lahan saat tahun 2017 yang memiliki luas 7,75 juta hektar. Keberadaan lahan pertanian yang terus menurun akan berdampak pada ketahanan pangan. Jika produksi pertanian dalam negeri kurang mencukupi untuk mencapai ketahanan pangan, maka pemerintah bisa menetapkan kebijakan impor bahan pangan, hal inilah yang sangat menghkawatirkan dan mengecewakan.

3. Harga penjualan hasil panen rendah. Penghasilan atau keuntungan petani di Indonesia masih rendah apabila dibandingkan dengan penghasilan dari sector lain. Bermula dari biaya proses awal sampai panen yang begitu tinggi, seringkali diabaikan oleh pemerintah dan tentunya pasar. Terdapat pertentangan yaitu, disatu sisi upah buruh tani semakin tinggi menurut pemilik lahan, tetapi disisi lain upah tersebut belum cukup bagi para buruh tani, sehingga menyebabkan rendahnya pendapatan buruh tani dan sebagian petani beralih masuk ke sector lain untuk kesejahteraannya. Menurunnya atau anjloknya harga saat panen, menjadi ketakutan dan kekecewaan tersendiri bagi petani. Kebijakan pemerintah terkait berlakunya harga pembelian pemerintah untuk gabah atau beras dari petani hendaknya mampu memberikan keuntungan bagi petani. Harga Pembelian Pemerintah (HPP) bertujuan untuk membeli gabah petani dengan harga yang sesuai, sehingga petani dapat meningkatkan pendapatan dan

9 "Jumlah Petani Hanya Tersisa 33,4 Juta Orang, Julukan Indonesia Negara Agraris Bisa Hilang radartegal.com," diakses 13 Juni 2021, http://radartegal.com/jumlah-petani-hanya-tersisa-334-juta-orangjulukan-indonesia-negara-agraris-bisa-hilang.8007.html.

${ }^{10}$ Eri Yusnita Arvianti dkk., "Gambaran Krisis Petani Muda Indonesia," AGRIEKONOMIKA 8, no. 2 (26 Desember 2019): 168-80, https://doi.org/10.21107/agriekonomika.v8i2.5429.

11 Wal'alfrit Gulo, Nurlina Harahap, Arie Hapsani Hasan Basri, “"Perspektif Generasi Muda Terhadap Usaha Bidang Pertanian Pangan di Kecamatan Moro'o Kabupaten Nias Barat," Jurnal Agrica Ekstensia vol.12, no. 1 (2018): 16-71.

${ }^{12}$ Tri Wahyuni, 2018, BPS Sebut Luas Lahan Pertanian Kian Menurun, diakses pada tanggal 26 April $2021 \quad$ https://www.cnnindonesia.com/ekonomi/20181025153705-92-341433/bps-sebut-luas-lahanpertanian-kian-menurun . 
produktivitasnya, akan tetapi fakta menunjukkan para petani justru menerima harga pembelian gabah mereka di bawah harga dasar. ${ }^{13}$

\section{PENETAPAN HARGA PEMBELIAN PEMERINTAH (HPP) UNTUK HARGA GABAH ATAU BERAS MENURUT PERMENDAG NOMOR 24 TAHUN 2020}

Adanya hukum bertujuan untuk menciptakan ketetiban diberbagai bidang kehidupan masyarakat sehari-hari. Manakala tidak ada aturan dalam masyarakat, maka akan terjadi kekacauan karena tidak adanya rambu-rambu dalam kehidupan seharihari. Hukum bertujuan mengatur ketertiban masyarakat diberbagai aspek kehidupan tentunya memberikan pedoman dalam segala hal agar tertata disetiap perilaku dan perbuatan. ${ }^{14}$

Fungsi hukum dalam pembangunan ekonomi di Indonesia, yaitu sebagai berikut:

1) Berperan aktif dalam pembangunan ekonomi, hukum selalu dibutuhkan untuk mengatur segala kegiatan ekonomi di masyarakat.

2) hukum memberikan perlindungan bagi pelaku ekonomi.

3) Kegiatan ekonomi diatur oleh hukum sebagai harapan terciptanya pembangunan ekonomi yang mengutamakan hak dan kepentingan masyarakat. ${ }^{15}$

Hakikat penetapan HPP gabah atau beras oleh pemerintah dilakukan sebagai upaya memberikan jaminan harga yang sesuai dengan yang ditetapkan untuk petani demi keberlangsungan produktifitasnya. Harapan pemerintah dalam menetapkan kebijakan gabah atau beras diantaranya yaitu; (1) agar produksi padi dapat ditingkatkan demi terpenuhinya kebutuhan pangan nasional, (2) Terciptanya harga gabah dan beras yang stabil di pasaran, sehingga pendapatan petani bisa meningkat, 3) peningkatan keuntungan petani, (4) meningkatnya pertumbuhan ekonomi nasional dari sector pertanian khususnya gabah atau padi.Kebijakan penetapan HPP gabah atau beras yang telah ditetapkan oleh pemerintah sudah memperhatikan kadar air dan butir patah beras. 16 Penerapan HPP gabah saat ini tetap memperhatikan kondisi kadar air dan kadar hampa hingga dengan pertimbangan bahwa sebagian besar petani memproduksi gabah pada kualitas tersebut, sehingga diharapkan mampu meningkatkan kesejahteraan mayoritas petani padi. ${ }^{17}$

Tujuan utama HPP Gabah dan beras yaitu agar penyerapan gabah atau beras oleh Bulog bisa optimal. Permendag 24 tahun 2020 merevisi besaran HPP yang diatur dalam Instruksi Presiden Nomor 5 Tahun 2015 tentang tentang Kebijakan Pengadaan

13 Muslim Mufti, "ANALISIS KRITIS TERHADAP SEKTOR PERTANIAN DI INDONESIA DALAM NEGARA KESEJAHTERAAN,” JISPO 1, no. $1 \quad$ (16 Maret 2016): 38-50, https://doi.org/10.15575/jispo.v1i1.713.

${ }^{14}$ Lili Rasjidi dan IB. Wyasa Putra, Hukum Sebagai Suatu Sistem (Bandung: PT. Remaja Rosdakarya, 1993). Hlm. 127

${ }^{15}$ Ade Maman Suherman, Pengantar Perbandingan Sistem Hukum:Civil Law, Common Law, Hukum Islam (Jakarta: Rajawali Press, 2008). Hlm. 10-11

${ }^{16}$ Nfn Hermanto dan Nfn Saptana, "Kebijakan Harga Beras Ditinjau dari Dimensi Penentu Harga," Forum penelitian Agro Ekonomi 35, no. 1 (8 Maret 2018): 31, https://doi.org/10.21082/fae.v35n1.2017.31-43.

${ }_{17}$ Muhammad Maulana dan Benny Rachman, "Harga Pembelian Pemerintah (Hpp) Gabah-Beras Tahun 2010: Efektivitas dan Implikasinya Terhadap Kualitas dan Pengadaan oleh Dolog," Analisis Kebijakan Pertanian 9, no. 4 (26 Agustus 2016): 331, https://doi.org/10.21082/akp.v9n4.2011.331-347. 
Gabah/Beras dan Penyaluran Beras oleh Pemerintah. ${ }^{18}$ Harga Pembelian Pemerintah (HPP) adalah Harga Pembelian Pemerintah untuk Gabah atau Beras yang selanjutnya disebut HPP Gabah atau Beras merupakan harga pembelian gabah atau beras oleh Pemerintah di tingkat produsen untuk dijadikan ketersediaan cadangan pangan Pemerintah, berupa cadangan beras Pemerintah dan keperluan untuk golongan tertentu. ${ }^{19}$

Rincian besaran HPP yang ditetapkan dalam Permendag 24 tahun 2020 yaitu: ${ }^{20}$

a. harga pembelian gabah kering panen dalam negeri dengan kualitas kadar air paling tinggi $25 \%$ dan kadar hampa/kotoran paling tinggi 10\% sebesar Rp 4.200/ kg di petani atau Rp 4.250/kg kilogram di penggilingan;

b. harga pembelian gabah kering giling dalam negeri dengan kualitas kadar air paling tinggi $14 \%$ dan kadar hampa/kotoran paling tinggi 3\% sebesar Rp $5.250 / \mathrm{kg}$ di penggilingan atau Rp 5.300/kg di gudang Perum BULOG; dan

c. harga pembelian beras dalam negeri dengan kualitas kadar air paling tinggi $14 \%$, butir patah paling tinggi $20 \%$, kadar menir paling tinggi $2 \%$, dan derajat sosoh paling sedikit 95\% sebesar Rp 8.300/kg di gudang Perum BULOG.

Upaya pemerintah memperbaiki perlindungan terhadap harga hasil panen petani melalui kebijakan HPP, diharapkan Perum BULOG bisa menyerap gabah atau beras dari petani secara maksimal untuk memperkuat stok Pemerintah dan dapat menjamin ketahanan pangan. Ketersediaan stok beras yang dikelola Perum Bulog diharapkan dapat menjaga keseimbangan dan ketersediaan pasokan pemenuhan pangan masyarakat Indonesia dalam jangka waktu pendek dan panjang. Permendag nomor 24 tahun 2020 merupakan instrumen keikutcampuran Pemerintah dalam kegiatan pasar agar tercapai kestabilan bersama. ${ }^{21}$

\section{EFEKTIFITAS PERMENDAG NOMOR 24 TAHUN 2020 DALAM MENGHADAPI KRISIS PETANI}

Efektivitas berasal dari kata efektif yang memiliki makna tercapainya keberhasilan dalam mencapai tujuan yang telah ditetapkan sesuai dengan yang semestinya. Efektivitas selalu terkait dengan dua hal yaitu hasil yang diharapkan dan hasil yang sesungguhnya dicapai. Efektivitas merupakan kemampuan melaksanakan tugas, fungsi (operasi kegiatan program atau misi) daripada suatu organisasi atau sejenisnya yang tidak adanya tekanan atau ketegangan diantara pelaksanaannya. Jadi efektivitas hukum dapat diartikan bahwa indikator efektivitas dalam arti tercapainya

\footnotetext{
18 "Permendag 24_2020.pdf," diakses $13 \quad$ Juli 2021 , https://ews.kemendag.go.id/file/policy/Permendag\%2024_2020.pdf.

19 "Permendag 24_2020.pdf."

20 "Permendag 24 -2020.pdf."

${ }^{21}$ Taufik Fajar, "Āturan HPP Baru, Mendag Minta Bulog Optimalkan Serap Beras Petani : Okezone Economy," https://economy.okezone.com/, 3 April 2020, https://economy.okezone.com/read/2020/04/03/320/2193726/aturan-hpp-baru-mendag-minta-bulog-optimalkanserap-beras-petani.
} 
sasaran atau tujuan yang telah ditentukan sebelumnya merupakan sebuah pengukuran dimana suatu target telah tercapai sesuai dengan apa yang telah direncanakan. ${ }^{22}$

Pemenuhan terhadap kebutuhan masyarakat merupakan keutamaan yang harus diperhatikan oleh pemerintah dan masyarakat sendiri. Tanggung jawab negara dalam menjamin kesejahteraan dan kemakmuran rakyat harus dilaksanakan dengan baik. Keseimbangan diberbagai sektor kehidupan tanpa mementingkan golongan sendiri merupakan amanat dari konstitusi. Kesejahteraan sosial merupakan prioritas tertinggi kebijakan publik negara Indonesia. ${ }^{23}$ Sektor ekonomi, sosial, budaya, pendidikan, kesehatan dan sektor lainnya harus sama-sama mendapatkan perhatian pemerintah guna tercapainya negara yang sejahtera dan maju.

Kebutuhan sosial dapat terpenuhi secara maksimal apabila bisa memaknai hukum dengan baik, yaitu sebagai kerangka acuan didalam bersikap dan berperilaku dalam segala aktifitas kehidupan.24 Negara yang bisa memenuhi kebutuhan warganya merupakan negara yang berhasil dalam tataran ekonomi. Pemenuhan kebutuhan warga negara, pemerintah harus berpegang teguh kepada Pancasila dan UUD 1945. ${ }^{25}$

Penetapan HPP gabah atau beras merupakan salah satu strategi Pemerintah dalam memberikan perlindungan bagi petani. Ketika harga gabah/beras di petani/penggilingan berada di bawah HPP, maka Perum Bulog wajib membeli gabah atau padi sesuai dengan HPP dan tetap memperhatikan syarat kualitas sesuai ketentuan. Tidak adanya perubahan harga eceran tertinggi di tingkat konsumen, maka tidak akan menaikan inflasi. Kebijakan tersebut hendaknya jangan sampai disalahgunakan oleh pihak-pihak yang tidak bertanggungjawab. Realita yang ada saat panen, petani mengalami ketidakpuasan dengan harga penjualan dibawah biaya produksi. Kondisi yang demikian, mengecewakan petani karena merasa tidak mendapatkan keuntungan yang layak.

Kebijakan HPP terkait harga gabah dan beras perlu dievaluasi oleh pemerintah. Harga penjualan yang sesuai, hendaknya bisa dinikmati oleh berbagai pihak baik dari produsen maupun konsumen. Ditemukan adanya harga penjualan yang menguntungkan konsumen, akan tetapi tidak bisa dinikmati oleh produsen. HPP gabah atau beras kurang bisa terlaksana dengan efektif dikarenakan yang terjadi adalah harga pasar lebih tinggi daripada harga yang ditetapkan oleh pemerintah, sehingga petani lebih memilih menjual berasnya ke pihak selain Bulog.

Dalam Permendag Nomor 24 Tahun 2020, harga GKP di tingkat petani ditetapkan sebesar Rp 4.200/kg. Sedangkan harga GKG, di tingkat penggilingan ditetapkan sebesar Rp5.205/kg dan di gudang Bulog Rp5.300/kg. Sementara itu, BPS mencatat selama Januari 2021, rata-rata harga GKP di tingkat petani sebesar Rp4.921/kg

\footnotetext{
${ }^{22}$ sabian usman.hal 13

23 Farida Sekti Pahlevi, "Harmonisasi Hukum Ekonomi Dalam Mewujudkan Kemakmuran Masyarakat Indonesia,” ACTIVA: Jurnal Ekonomi Syariah 2, no. 1 (30 April 2019): 35-52.

${ }^{24}$ Soerjono Soekanto. Pokok-pokok Sosiologi Hukum. Jakarta: PT Raja Grafindo Persada. 2016, 4243 Indonesia."

25 Pahlevi, "Harmonisasi Hukum Ekonomi Dalam Mewujudkan Kemakmuran Masyarakat
} 
atau naik 3,03 persen dan di tingkat penggilingan Rp5.026/ kg atau naik 3,10 persen dibandingkan harga gabah kualitas yang sama pada bulan sebelumnya. Sedangkan, rata-rata harga GKG di tingkat petani Rp5.318/ kg atau turun 0,73 persen dan di tingkat penggilingan Rp5.432/ kg atau turun 0,80 persen. Kesenjangan harga ini pada akhirnya membuat petani lebih memilih untuk menjual beras kepada pembeli swasta yang mau membayar lebih mahal dari harga yang sudah ditetapkan.

Hal demikian mengakibatkan adanya kompetisi antara Perum Bulog dan pihak swasta yang berpengaruh kepada penyerapan hasil panen Perum Bulog tidak bisa maksimal. Berdasarkan data Bulog pada 2020, jumlah serapan beras Bulog dari petani menurun dari 2,96 juta ton GKG pada 2016 menjadi 1,48 juta ton pada 2018 hasil ini terjadi karena Bulog tidak mampu bersaing dengan adanya keterbatasan anggaran. ${ }^{26}$

Indonesia menganut system ekonomi Pancasila yaitu bersumber dari Pancasila khususnya sila kelima "Keadilan sosial bagi seluruh rakyat Indonesia" dan amanat Pasal 27 ayat (2), Pasal 33-34 UUD 1945 (Amandemen ke 4). Sila kelima ini menjelaskan bahwa semua orientasi berbangsa dan bernegara, politik ekonomi, hukum, sosial dan budaya, adalah dijiwai semangat keadilan menyeluruh dan diperuntukkan bagi seluruh rakyat Indonesia. ${ }^{27}$ Dengan demikian, keberadaan sistem Ekonomi Pancasila sudah ada dengan Pancasila sebagai landasan idiilnya dan UUD1945 sebagai landasan konstitusionalnya.

Bangunan sistem ekonomi pancasila menurut Munawar Ismail: 28
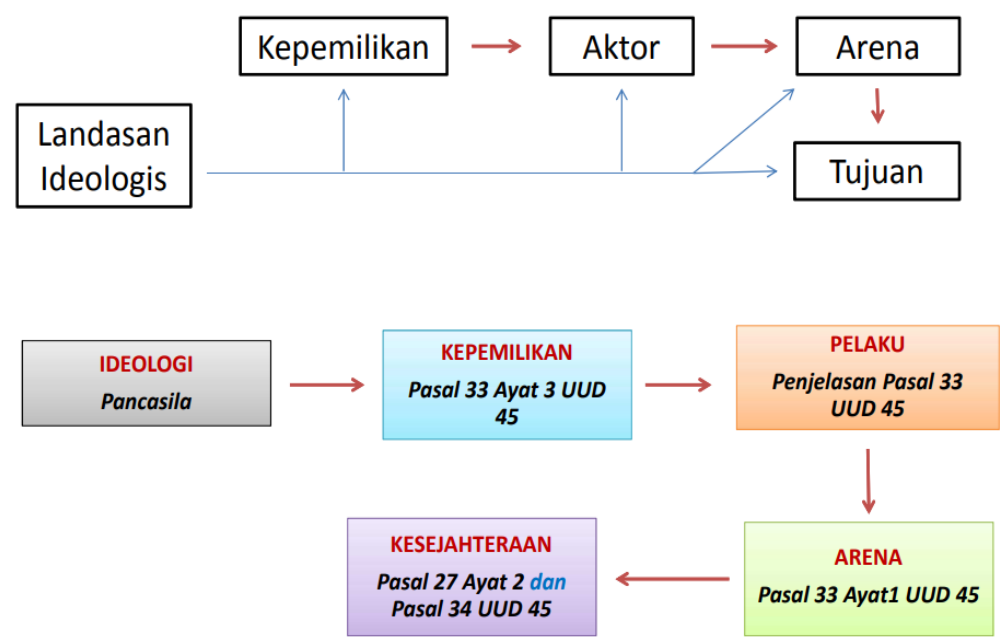

\footnotetext{
${ }^{26}$ C. N. N. Indonesia, "Lindungi Petani, HET dan HPP Beras Diminta Dievaluasi," ekonomi, diakses 5 Juli 2021, https://www.cnnindonesia.com/ekonomi/20210215153902-92-606448/lindungi-petani-het-dan-hppberas-diminta-dievaluasi.

${ }^{27}$ Khusus dalam hal ekonomi diperjelas lagi dalam Pasal 27 ayat (2) berbunyi; tiap-tiap warga negara berhak atas pekerjaan dan penghidupan yang layak bagi kemanusiaan. Sedangkan Pasal 33 berbunyi;

1) Perekonomian disusun sebagai usaha bersama berdasar atas asas kekeluargaan;

2) Cabang-cabang produksi yang penting bagi negara dan yang menguasai hajat hidup orang banyak dikuasasi oleh Negara;

${ }^{28}$ Munawir Ismail..., akses 14 Maret 2019 hlm. 12
} 
Komponen sistem ekonomi mengandung arti setiap sistem tersusun dari komponen yang saling terkait sehingga membentuk satuan gerakan yang holistik. Komponen sistem ekonomi dapat diturunkan dari rangkaian kegiatan ekonomi, dimanan kegiatan ekonomi dilakukan oleh para pelaku ekonomi (agen) yang memiliki sumber daya yang berinteraksi di suatu arena untuk mencapai tujuan masing-masing. Jadi komponen minimum suatu sistem ekonomi adalah: ${ }^{29}$ (1) Kepemilikan sumber daya, (2) Aktor ekonomi, (3) Arena dimana aktivitas ekonomi diselenggarakan, (4) Tujuan. Pancasila dapat disebut sebagai bingkai dari Sistem Hukum Pancasila, sebuah sistem yang khas di Indonesia dan berbeda dari sistem hukum negara-negara lain. Satjipto Rahardjo, menyebut bahwa hukum Pancasila mencerminkan kekhasan bangsa Indonesia yang penuh dengan sikap kekeluargaan dan gotong royong yang karenanya memang berbeda dengan sistem hukum yang lain. ${ }^{30}$

Terkait efektifitas permendag nomor 24 tahun 2020 dalam menghadapi krisis petani di Indonesia, dengan adanya penetapan HPP, yaitu;

a. Stok beras dalam negeri aman. Bulog menyampaikan ketersediaan beras per bulan Juli 2021 dalam kondisi aman. Dalam kondisi pandemi Covid -19 yang pemberlakuan pembatasan kegiatan masyarakat (PPKM) stok beras aman sehingga wacana impor yang sempat menjadi kabar meresahkan petani belum menjadi pertimbangan. Stok beras per bulan Juli berdasarkan laporan perum bulog, stok beras pemerintah 1,37 juta ton dan stok komersial 13.969 ton. ${ }^{31}$ Penyerapan gabah dan beras oleh Bulog bisa meningkat, akan tetapi disatu sisi petani tidak cukup puas dengan harga yang ditetapkan. Dari fakta yang ada, petani lebih memilih menjual hasil panennya ke pihak swasta manakala harga dari BULOG lebih rendah.

b. Permendag nomor 24 tahun 2020 ternyata belum mampu untuk meningkatkan gairah masyarakat khususnya generasi muda untuk menjadi petani. Dari data yang disampaikan oleh BPS membuktikan bahwa jumlah petani dari tahun ke tahun belum menunjukkan peningkatan yang signifikan bahkan cenderung menurun. keuntungan dari penjualan hasil panen masih belum bisa dirasakan oleh petani, bahkan tidak jarang petani mengalami kerugian karena dalam proses awal sampai dengan panen biayanya lebih tinggi, palagi tidak diimbangi dengan adanya penetapan harga pupuk yang murah dan melimpah.

c. Penetapan HPP oleh pemerintah dirasa belum memberikan harga yang sesuai dengan produktifitas petani. Harga pokok penjualan (HPP) gabah atau beras yang ditetapkan pemerintah masih berada di bawah biaya produksi petani. Bisa dibuktikan dengan melihat Permendag Nomor 24 Tahun 2020, yaitu HPP GKP sebesar Rp 4.200/kg, sementara berdasarkan kajian Asosiasi Bank Benih dan

\footnotetext{
${ }^{29}$ Munawir Ismail.... akses 14 Maret 2019 ,hlm. 10

${ }^{30}$ Moh. Mahfud MD, Perdebatan Hukum Tata Negara Pasca Amandemen Konstitusi, Pustaka LP3ES Indonesia, Jakarta, 2007, hlm. 7.

31 "PPKM Darurat Mulai 3 Juli, Begini Kondisi Stok Beras Nasional | Ekonomi," Bisnis.com, 1 Juli 2021, https://ekonomi.bisnis.com/read/20210701/12/1412596/ppkm-darurat-mulai-3-juli-begini-kondisi-stokberas-nasional.
} 
Teknologi Tani Indonesia (AB2TI) pada 2019, biaya produksi gabah di dalam negeri mencapai Rp 4.523/kg. hal ini membuktikan bahwa biaya produksi lebih tinggi dari harga penjualan.

Dari data yang diperoleh peneliti dari berbagai sumber, maka perlu ada upaya dalam menghadapi krisis petani di Indonesia. Upaya yang harus dilakukan dalam menghadapi krisis petani diantaranya yaitu:

a. Meningkatkan sosialisasi pertanian guna memberikan wawasan kepada masyarakat bahwa Indonesia adalah negara agraris, negara yang kaya, negara yang memiliki tanah yang subur sehingga tidak boleh berputus asa dalam usaha tani.

b. Kerjasama berbagai pihak terkait dengan pertanian dalam hal pemenuhan kebutuhan petani dalam hal proses awal sampai dengan pemasaran hasil panen. Keunggulan hasil pertanian gabah atau padi Indonesia daripada negara lain harus diperkenalkan dan dipasarkan dengan maksimal, agar tidak ada lagi kebijakan impor beras yang menjadi kekhawatiran dan kekecewaan petani Indonesia. Kecukupan pangan dalam negeri diimbangi dengan ekspor gabah atau beras harus menjadi prioritas pemerintah Indonesia.

c. Meningkatkan harga jual gabah atau padi. Kekecewaan petani yang sering ditemukan dilapangan dari dulu sampai dengan sekarang adalah harga. Petani merasa tidak mendapatkan keuntungan yang layak bahkan ditemukan juga mengalami kerugian. Harga penjualan hasil panen gabah atau beras yang tidak memihak petani, harus segera disikapi oleh pemerintah. HPP yang lebih tinggi bisa diupayakan oleh pemerintah, dengan demikian diharapkan mampu meningkatkan regenerasi petani di Indonesia dan julukan negara agraris yang gemah ripah loh jinawi bisa terjaga kenyataannya.

\section{KESIMPULAN}

Indonesia mengalami penurunan jumlah petani dari tahun ke tahun. Kekhawatiran akan terjadinya krisis petani menjadi pembahasan yang harus diprioritaskan. Kebijakan HPP gabah atau beras secara terus menerus disempurnakan dan disesuaikan dengan situasi dan kondisi yang ada. Kebijakan HPP gabah atau beras selain ditujukan untuk melindungi harga gabah/beras di tingkat petani hendaknya juga bertujuan untuk memberikan kesejahteraan petani agar minat masyarakat menjadi petani tidak menurun. Pemerintah diharapkan mampu melakukan penyempurnaan kebijakan HPP agar lebih baik dalam rangka meningkatkan implementasi kebijakan harga beras yang efektif dan efisien. Harmonisasi hubungan antara petani produsen, industri pengolahan, lembaga pemasaran, hingga ke tingkat konsumen dalam suatu kegiatan ekonomi dapat memberikan keuntungan yang sesuai bagi masing-masing pihak sangat diperlukan.

Sebagai negara agraris, idealnya sektor pertanian selain dapat meningkatkan perekonomian nasional juga dapat meningkatkan taraf hidup serta kesejahteraan petani. Maka, sudah selayaknya sektor pertanian didukung dengan kebijakan dan 
aturan yang mengakomodasi kepentingan para petani lokal demi tercapainya kesejahteraan masyarakat Indonesia serta mencegah krisis pertanian di Indonesia. Kebijakan dan peraturan hukum sektor pertanian harus memberikan keadilan hukum bagi para petani. Adanya efektifitas hukum pada sektor pertanian diharapkan mampu mengakomodir segala aspirasi dan kepentingan petani melalui regulasi dan kebijakan yang memihak pada kehidupan petani. Melalui regulasi dan kebijakan yang efektif serta menguntungkan petani, taraf hidup dan kesejahteraan petani dapat ditingkatkan. Dengan demikian, perlu adanya peran pemerintah yang serius dalam menyelesaikan problematika dan tantangan sektor pertanian serta mewujudkan keadilan hukum bagi para petani agar persoalan yang menyebabkan krisis pertanian dapat teratasi.

\section{DAFTAR PUSTAKA}

Ade Maman Suherman. Pengantar Perbandingan Sistem Hukum:Civil Law, Common Law, Hukum Islam. Jakarta: Rajawali Press, 2008.

Arvianti, Eri Yusnita, Masyhuri Masyhuri, Lestari Rahayu Waluyati, dan Dwijono Hadi Darwanto. "Gambaran Krisis Petani Muda Indonesia." AGRIEKONOMIKA 8, no. 2 (26 Desember 2019): 168-80.

https:// doi.org/10.21107/agriekonomika.v8i2.5429.

"Badan Pusat Statistik." Diakses 2 Juli 2021.

https://www.bps.go.id/indicator/36/1052/1/kasus-harga-gabah-di-bawahharga-pembelian-pemerintah-hpp-bulanan.html.

FB, URL PROFIL. "Pengertian GKP, GKS dan GKG dalam dunia Pertanian." Sampul Pertanian (blog). Diakses 2 Juli 2021.

https://www.sampulpertanian.com/2017/10/pengertian-gkp-gks-dan-gkgdalam-dunia.html.

Hermanto, Nfn, dan Nfn Saptana. “Kebijakan Harga Beras Ditinjau dari Dimensi Penentu Harga." Forum penelitian Agro Ekonomi 35, no. 1 (8 Maret 2018): 31. https://doi.org/10.21082/fae.v35n1.2017.31-43.

Indonesia, C. N. N. “Lindungi Petani, HET dan HPP Beras Diminta Dievaluasi." ekonomi. Diakses 5 Juli 2021.

https://www.cnnindonesia.com/ekonomi/20210215153902-92-606448/lindungipetani-het-dan-hpp-beras-diminta-dievaluasi.

Iskandar Putong. Teori Ekonomi Mikro. Jakarta: Mitra Wacana Media, 2005.

Jakarta, Koran. "Pendampingan ke Petani Mesti Terus Diperluas | Koran Jakarta." LINE TODAY. Diakses 14 Juni 2021. https:// today.line.me/id/v2/article/1eaB6z.

Julius $r$ latumaresa. Perekonomian Indonesia Dan Dinamika Ekonomi Global. Jakarta: Mitra Wacana Media, 2015.

“Jumlah Petani Hanya Tersisa 33,4 Juta Orang, Julukan Indonesia Negara Agraris Bisa Hilang - radartegal.com." Diakses 13 Juni 2021. http:/ / radartegal.com/jumlahpetani-hanya-tersisa-334-juta-orang-julukan-indonesia-negara-agraris-bisahilang.8007.html. 
Lili Rasjidi dan IB. Wyasa Putra. Hukum Sebagai Suatu Sistem. Bandung: PT. Remaja Rosdakarya, 1993.

Maulana, Muhammad, dan Benny Rachman. “Harga Pembelian Pemerintah (Hpp) Gabah-Beras Tahun 2010: Efektivitas dan Implikasinya Terhadap Kualitas dan Pengadaan oleh Dolog." Analisis Kebijakan Pertanian 9, no. 4 (26 Agustus 2016): 331. https://doi.org/10.21082/akp.v9n4.2011.331-347.

Mufti, Muslim. “ANALISIS KRITIS TERHADAP SEKTOR PERTANIAN DI INDONESIA DALAM NEGARA KESEJAHTERAAN." JISPO 1, no. 1 (16 Maret 2016): 38-50. https:// doi.org/10.15575/jispo.v1i1.713.

Pahlevi, Farida Sekti. "Harmonisasi Hukum Ekonomi Dalam Mewujudkan Kemakmuran Masyarakat Indonesia." ACTIVA: Jurnal Ekonomi Syariah 2, no. 1 (30 April 2019): 35-52.

"Permendag 24_2020.pdf." Diakses 13 Juli 2021.

https://ews.kemendag.go.id/file/policy/Permendag\%2024_2020.pdf.

Bisnis.com. “PPKM Darurat Mulai 3 Juli, Begini Kondisi Stok Beras Nasional | Ekonomi," 1 Juli 2021.

https:/ / ekonomi.bisnis.com/read/20210701/12/1412596/ppkm-darurat-mulai3-juli-begini-kondisi-stok-beras-nasional.

sabian usman. Dasar-Dasar Sosiologi. Yogyakarta: Pustaka Belajar, 2009.

SUARANTB.com. “Kecewa Harga Gabah Anjlok, Petani Dompu Potong Padinya | SuaraNTB," 30 Maret 2021. https:/ / www.suarantb.com/kecewa-harga-gabahanjlok-petani-dompu-potong-padinya/.

Sudjarwo, Eko. “Harga Gabah Murah, Petani Keluhkan Kebijakan Pemerintah Impor Beras." detiknews. Diakses 5 Juli 2021. https:/ / news.detik.com/berita-jawatimur/d-5499504/harga-gabah-murah-petani-keluhkan-kebijakan-pemerintahimpor-beras.

Taufik Fajar. “Aturan HPP Baru, Mendag Minta Bulog Optimalkan Serap Beras Petani : Okezone Economy." https:/ / economy.okezone.com/, 3 April 2020. https://economy.okezone.com/read/2020/04/03/320/2193726/aturan-hppbaru-mendag-minta-bulog-optimalkan-serap-beras-petani.

Wal' alfrit Gulo, Nurlina Harahap, Arie Hapsani Hasan Basri. “'Perspektif Generasi Muda Terhadap Usaha Bidang Pertanian Pangan di Kecamatan Moro'o Kabupaten Nias Barat.'" Jurnal Agrica Ekstensia vol.12, no. 1 (2018): 16-71. 